ção consciente destinada a doentes não colaborantes. É uma consulta especial, com uma dinâmica diferente de tantas outras consultas, havendo um trabalho multidisciplinar com excelentes resultados em prol dos pacientes.

Descrição do caso clínico: Os autores descrevem o caso de uma doente de 23 anos, com Síndrome de Dravet, não colaborante, com necessidade de sedação para realização de tratamentos. O Síndrome de Dravet, uma patologia rara, caracterizada por uma encefalopatia epilética associada a um défice cognitivo progressivo, com crises convulsivas de difícil controlo farmacológico. A paciente é polimedicada com levetiracetam, ácido valpróico, topiramato e clobazam. Como efeitos secundários desta medicação está descrito o aumento gengival, neste caso apresentava-se com um aumento gengival generalizado exuberante, com interferência na oclusão e estética. De forma a repor a funcionalidade oclusal, e dada a boa colaboração da doente em consultas de sedação anteriores, realizou-se, em maio 2016, gengivectomia cirúrgica no $1 .^{\circ}$ e $2 .^{\circ}$ quadrantes, com posterior aplicação de goteira de silicone. Ao fim de 1 ano, mantém-se com um excelente resultado, com melhoria funcional na oclusão e estética.

Discussão e conclusões: O tratamento de doentes com défices cognitivos, não colaborantes é um desafio. De notar que para além do habitual seguimento que estes doentes requerem, salientamos e demonstramos que é possível realizar tratamentos mais diferenciados sem ser necessário uma anestesia geral, evitando assim todos os riscos que essa técnica comporta. Para além disso esta técnica é muito mais cómoda para o paciente e tutores, não necessitando de internamento. Por seu lado a gengivectomia é uma técnica com excelentes resultados nos casos de aumento gengival de causa iatrogénica.

http://doi.org/10.24873/j.rpemd.2017.12.050

\#018 De Hiperplasia Fibromatosa Inflamatória a Fibroma Ossificante Periférico - caso clínico

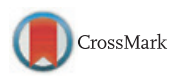

Luísa Figueiredo*, Afonso Martins, Cátia Mateus, Eduardo Dutra, Ana Fernandes, Francisco Proença

Centro Hospitalar Lisboa Central - Hospital S. José, Centro Hospitalar Lisboa Central - Hospital D. Estefânia

Introdução: O Fibroma Ossificante Periférico é uma hiperplasia inflamatória reativa benigna, mais comum no género feminino e de etiologia desconhecida. Relaciona-se com a existência de placa bacteriana, cálculo dentário, próteses mal adaptadas, entre outros fatores iatrogénicos. Ocorre quase exclusivamente na gengiva inserida e geralmente envolve a papila. O diagnóstico é sobretudo histopatológico, caracterizando-se pela presença de focos mineralizados num estroma de tecido conjuntivo com inúmeros fibroblastos.

Descrição do caso clínico: Mulher de 61 anos, raça negra, seguida no Serviço de Estomatologia do Hospital de S. José por lesões exofíticas, recidivantes, do 2 . $^{\circ} \mathrm{Q}$. Foram realizadas várias biopsias: 2010 (fibroma periférico traumático com esboço de formação de trabéculas ósseas), 2012 (inflamação linfo-plasmocitária e tecido ósseo) e 2014 (hiperplasia fibromatosa inflamatória). Regressa em Maio de 2017 por reaparecimento de lesão assintomática, com características semelhantes às anteriores e 3 semanas de evolução. Apresentava lesão exofítica séssil de coloração rósea, bem delimitada, lisa com 3 x 1.5 cm envolvendo os dentes 2.3, 2.4 (deslocado para vestibular e distal) e 2.5, os quais apresentavam mobilidade de grau II/III. A doente apresentava doença periodontal severa não controlada (mobilidade grau II/III em todos os dentes). Era portadora de prótese parcial superior dento-muco-suportada mal adaptada. A radiografia retro-alveolar mostrava focos radiopacos de pequena dimensão e sugestivos de calcificação. Na ortopantomografia não eram visíveis estas calcificações. Colocados os diagnósticos diferenciais de granuloma piogénico, lesão periférica de células gigantes, hiperplasia fibromatosa inflamatória (previamente diagnosticado) e fibroma ossificante periférico, procedeu-se a biópsia incisional da lesão e extração de 2.4. O estudo anátomo-patológico revelou tratar-se de Fibroma Ossificante Periférico com intensa inflamação. Planeia-se excisão total da lesão e eliminação dos fatores traumáticos. Programa-se seguimento em consulta de Periodontologia e reabilitação protética adequada.

Discussão e conclusões: Entre outros, o interesse clínico do caso radica na demonstração de que a recidiva de algumas lesões gengivais justifica a necessidade de seguimento e a repetição de biópsias. Salienta-se ainda a importância da imagiologia intra-oral neste tipo de lesões.

http://doi.org/10.24873/j.rpemd.2017.12.051

\section{\#019 Sobredentadura sobre Barra Fresada com Equators: Caso Clínico}

Hugo Sá Pinto*, Gustavo Silva Pereira, Sampaio Fernandes, José Mário Rocha, Paulo Júlio, Ricardo Duarte

Faculdade Medicina Dentária da Universidade do Porto, Universidade Federal do Rio Grande do Norte - Natal - RN - Brasil

Introdução: A reabilitação de arcadas totalmente desdentadas constitui um dos maiores desafios na área da reabilitação oral. Apesar da ausência total de peças dentárias ter vindo a ser menos prevalente ao longo do tempo, as sobredentaduras são uma das possibilidades de reabilitação protética bastante viável, sendo muitas vezes considerada a primeira abordagem perante pacientes com ausência total de peças dentárias, condições ósseas desfavoráveis e/ou poder económico mais limitado. A utilização de próteses com quatro implantes e uma barra na região frontal da mandíbula tem-se tornado o tratamento de escolha para próteses removíveis mandibulares. A escolha do sistema de retenção está dependente do espaço protético disponível, necessidade de manutenção, distribuição de forças para os tecidos duros, moles, implantes e nível de retenção. Quando a mandíbula apresenta uma forma larga ou em V, três ou quatro implantes irão providenciar um desenho da prótese e da barra mais favoráveis.

Descrição do caso clínico: Paciente do sexo masculino de 64 idade, portador de sobredentadura na maxila com sistema de retenção tipo cavalete. Dada a sua satisfação com o sistema recorreu à FMDUP para realizar reabilitação na mandibula com o mesmo tipo de sistema. Procedeu-se à colocação de 